\title{
Marcin Rzepka
}

Pontifical University of John Paul II in Kraków

Jagiellonian University in Kraków

\section{Payām-e Āšuriyān - the Assyro-Chaldean publications in the Persian language in post- revolutionary Iran}

The problem of issuing the press and publications by one of the constitutionally recognized religious minorities (aqaliyat-e dini) ${ }^{1}$ in the Islamic Republic of Iran should involve us in a discussion on some main questions. Firstly, how big the community is; secondly, in which language its books or press are published, and finally, what titles and with what frequency are issued.

The term "Assyrians" (Persian: Āšuriyān) is used to describe modern Eastern Syrian Christian communities living in Iran, ${ }^{2}$ geographically distributed mostly in the western part of Iran (Azerbaijan Province) and Tehran. They are divided into: 1) the Assyrian Church of the East (Kelisāa-ye šarq-e Āšuri); 2) the Catholic Chaldean Church (Kelisā-ye Kātuli-Kaldāni Āšuri); 3) the Assyrian Evangelical Church (Kelisāa-ye Enğili Āšuri); 4) the Pentecostal Assyrian Church (Kelisāa-ye ğamā'at-e rabbani Āšuri). ${ }^{3}$

At the beginning of the $19^{\text {th }}$ century, along with the coming of Christian missionaries, the situation of the Assyrian community was changing rapidly. The introduction of modern educational system and the establishment of the press in the city of Urmia had a positive effect on the growth of self-consciousness of the Assyrians and their political and social aspirations.

${ }^{1}$ Cf. Constitution of the Islamic Republic of Iran, tr. from Persian into English by H. Algar, Berkeley 1980.

${ }^{2}$ The process of development of the modern concept of the Assyrians among these people started in the $19^{\text {th }}$ century.

${ }^{3}$ Cf. N. A. Horner, A Handbook on the Christian Communities in Iran 1970, Iran 1971; $\bar{A}$. Rošdi, Sar-gozašt-e masihiyat dar Irān-zamin [History of the Christianity in Iran], Elam Publications 2006, pp. 130-133; generally on the Christianity in Iran see, R. Waterfield, Christians in Persia. Assyrians, Armenians, Roman Catholics and Protestants, London 1973. 
They took part in the constitutional movement in 1906-1911 as well as in all the main events in the modern history of Iran. ${ }^{4}$

\section{Islamic revolution - a new paradigm for the Assyrians}

The Islamic Revolution had a great impact on all religious minorities in Iran. In fact, the new socio-political situation evoked new challenges for them, especially in describing their self-identity in the Muslim context.

The relations between the Islamic State and minorities were matters of debates over the new constitution, which was accepted in 1979 and slightly modified ten years later, in 1989. The constitution reflecting the new state ideology defined religious minorities as Jews (Kalimi), Zoroastrians (Zartoštiyān) and Christians (Masihiyān) - without making any divisions between them (in Art. 13). The Constitution guaranteed the right to observe religious rituals and conduct religious education in a free way. ${ }^{5}$

In the part referring to the linguistic policy of the State the Constitution emphasized the role of Persian as the official language and gave ethnic groups the right to use their national languages in textbooks or other publications.

A very important task for the newly established regulations was the constitutional article 64 concerning parliamentary elections. The article states that all the religious minorities living in Iran (described in Art. 13) have the right to choose their own representatives to the Iranian parliament. In this Article the understanding of the minorities is based on both religious as well as ethnic criteria.

The following minorities were counted: Jews (with the right to choose 1 representative), Zoroastrian (1 representative), Armenian ( 2 representatives - one from the north and one from the south of Iran) and Assyrian (1 representative). The regulation made the Assyrians confused. Divided into two communities, the Assyrian Church and the Chaldean Church, they tried to obtain two posts. However, their petition, in spite of the active role of Sergen Bait Ushana in persuading that the Assyrian and Chaldean communities are as big as the Armenian one and reached 70-80 thousand members, found no interest among the Constitutional Assembly of Experts. ${ }^{6}$ Thus the Assyrians and Chaldeans have one common deputy. At present the deputy post is occupied by Yonathan Betkolia, who is also the General Secretary of the Assyrian Universal Alliance

\footnotetext{
${ }^{4}$ Cf. E. Naby, “The Assyrians of Iran: Reunification of a Millat 1906-1914,” International Journal of Middle East Studies 8/2 (1977), pp. 237-249; E. Abrahamian, Iran between two Revolutions, Princeton 1983.

${ }^{5}$ See E. Sanasarian, Religious Minorities in Iran, Cambridge 2000, p. 67, which refers to the discussion of art. 13 in detail.

${ }^{6}$ Ibid., p. 69.
} 
(Persian: Anğāman-e Āšurihā-ye ğahān). For many years he was also the editor of the Payām-e Āšuriyān [The Message of the Assyrians] magazine.

\section{Population of the Assyrian (Chaldean)}

No proper and valuable research has been done concerning the population of the religious minorities in Iran. The estimations are based on personal interviews and observation rather than systematic studies, which are practically impossible to be conducted. Such a problem was confirmed by Prof. Mohammad Hemmasi who analyzed demographical changes among the religious minorities after the Islamic Revolution. ${ }^{7}$ In the case of Christian population (as well as Jewish) he noted an incredible decrease in the population compared to the situation from the census of 1976. At that time the Armenian population amounted to 104,000 whereas the Assyrian one was only 25,000 and the others (including the Protestants and Chaldeans) $-40,000 .{ }^{8}$ The information collected directly from the Assyrians (and the Chaldeans) also differed and allowed estimating the total population between 24,000 and 40,000.

For the Chaldeans in the Tehran diocese, led by Bishop Ramzi Garmou, according to his estimation, we can assume to be 3,000, which means 600 families. ${ }^{9}$ Ramzi also informs about emigration as the main problem of Christianity in the Middle East. Tehran, which is the centre for all religious minorities in Iran, can be treated as the main location of the Assyrians and their activities. There are nine churches and two schools there.

The Chaldean Church in Iran includes the Metropolis of Tehran, the Metropolis of Urmia, the Archeparchy of Ahwaz and the Eparchy of Salmas.

\section{Language and religion}

The issue of the language is a crucial matter while disputing minorities in modern Iran, especially the Persian language, which is connected to Islam and sometimes possessed by the Muslims and treated as a tool to exclude others. ${ }^{10}$

${ }^{7}$ C. V. Prorok, M. Hemmasi, "Demographic Changes in Iran's Officially Recognized Religious Minority Populations Since the Islamic Revolution," African and Asian Studies 1 (2002) no. 2, pp. 63-86.

${ }^{8}$ Some statistical data (for 1950-1951 and 1970-1971) were published by H. de Mauroy, Les Assyro-Chaldéens dans l'Iran d'aujourd'hui, Paris 1978.

${ }^{9}$ V. Denha-Garmo, "Life as a Persian Chaldean Bishop Ramzi Garmo talks about life for Christians in Iran," Chaldean News December 2, 2009, http:/www.chaldeannews.com/index. cfm? articleid $=2039$

${ }^{10}$ The problem of the Persian languages was also one of the main topics of debate concerning the term "religious minorities" during the Constitutional period - the Zoroastrians argued that since they used Persian and were the natives of Iran they were not to be equalized with other so-called minorities in Iran. 
It is also a problem for the Chaldean community (and perhaps to a smaller degree for other Assyrians). While referring to the Chaldean view on the language, we should consider the tensions between their use of the native and the Persian languages. Such a tension can be seen in Bishop Ramzi's speeches and deeds.

The Syriac language guarantees to preserve the cultural identity of Chaldeans whereas the Persian language shows openness and universality of the Church in Iran, i.e., the Chaldean Catholic Church. Ramzi Garmou, who was appointed bishop in 1996, succeeding Bishop Issawi, firmly states that the promotion of the Persian language among Christians in Iran and its use in the Christian liturgy should be one of the goals of the Church leaders.

To understand the importance of such a decision and statements one should remember the situation of the use of the Persian language by Christians and the reactions of the Muslim authorities. In 1994 a protestant bishop of Armenian origin, Haik Hovsepian-Mehr, received the following governmental instruction, "No church service must be conducted in the Persian language. All members must be issued with membership card and their admittance to the services would be on production of the appropriate card. Photocopies of these cards and appropriate membership lists with their addresses should be given to competent authorities. Sunday meetings were to be for members only. No meeting to be held on any other day, in particular Friday." It shows, among other things, that, according to the authorities the Persian language should be preserved as a Muslim language. Taking this context into consideration the promotion of the use of the Persian language in the Christian liturgy simply seems to be brave.

It is worth quoting the words of Bishop Ramzi Garmou spoken after the death of John Paul II, "The use of Farsi in the liturgy is a service of faith. We are not at the service of a specific ethnic group, but of the whole nation. If every religious community were to attend solely to its own ethnic group what would happen tomorrow to the Church in Iran?"12

It is also an important problem for the Christian converts such as Bishop Hassan Dehqani-Tafti (1920-2008), who shortly after the revolution introduced the term masihiyān-e fārsi-zabān (Persian-speaking Christian) not referring to ethnicity. ${ }^{13}$ The Persian language became the space of a political and religious struggle.

The Persian language may be considered to be a useful tool among Christians of various confessions and ethnic origins. From such a perspective the Persian language Chaldean press and publications should be analyzed.

${ }^{11}$ Cf. K. Spellman, Religion and nation. Iranian local and transnational networks in Britain, New York-Oxford 2006, p. 167.

${ }^{12}$ C. Eid, Voyage in Iran, Where Even the Catechism Has Khomeini on the Cover, http:// chiesa.espresso.repubblica.it/articolo/41931?eng=y [30.10.2010]

${ }^{13} \mathrm{H}$. Dehqani-Tafti, Masih va masihiyat nazd-e Irāniyān [Christ and Christianity among the Iranians], vol. 3, Sohrab Books 1994, p. 410. 


\section{The Assyrian Organization in Tehran and the Assyrian press in Iran}

The Assyrian Organization in Tehran (Persian: Anğāman-e Āšurihāa-ye Tehrān) is one of the leading Assyrian socio-cultural organizations in Iran being engaged in the publishing of the Assyrian press, magazines, etc. It was established during the second decade of the $20^{\text {th }}$ century as a kind of a club. Apart from that, in Tehran there is also the Assyrian Youth Cultural Society. ${ }^{14}$

The activity in the field of publishing characteristic of the above-mentioned organization represented part of the history of the Assyrian press in Iran. The history has its beginning in the middle of the $19^{\text {th }}$ century when, with the support of the American missionary Justin Perkins, ${ }^{15}$ the first issue of the monthly magazine called Zahrira d-Bahra (Ray of light) was published in Urmia. ${ }^{16}$ The city was inhabited mostly by Christians at that time and for a long period it was the main place where Christians developed their press activities.

Perkins'magazine was published from 1849 to 1918 in the Syriac language but it contained a page in Persian with some political and social news. Undoubtedly, Justin Perkins is best known for his contribution to the development of the Modern Syriac language, but he seems to have also noticed the importance of Persian. In any case, it is Perkins' actions that started the Assyrian publications in Iran.

According to Hanibal Georgiz, the author of the text published in the Payām-e Āšuriyān entitled, Nazari-ye eğmāli be ğarāid-e Āšurihāaye Irān (A Brief view on the Assyrian publications in Iran), during the history of the Assyrian press in Iran 28 titles have appeared up till now. ${ }^{17}$

We can observe certain tendencies in the history: till the 1940s most magazines and papers were published in Urmia, and afterwards in Tehran. The publications reflect the political changes in Iran, and thus in the years 1951-1953, when three titles were published, they inform about the Mohammad Mosaddeq; from 1953 up to the revolution they inform about the "white revolution," the period when the Mohammad Reza Szah's regime was rather peaceful for the Assyrians. The Islamic revolution was a turning point. During the years 1981-1983 the paper Ishtar was published, but the editors understood the paper's role as a medium to popularize

${ }^{14}$ In 1974 the organization founded the National Assyrian Library, cf. Rudolf Macuch and Arian Ishaya, Assyrians in Iran, Encyclopaedia Iranica, Online Edition, 1987, available at: http:// www.iranica.com/articles/assyrians-in-iran [30.10.2010]

${ }^{15} \mathrm{~J}$. Perkins, A residence of eight years in Persia among the Nestorian Christian, Andover 1843.

${ }^{16}$ On the history of the Presbyterian mission and the Perkins' activity, see J. Elder, History of American Presbyterian Mission to Iran (1834-1960), Tehran.

${ }^{17}$ Payām-e Āšuriyān 6 (1998), pp. 14-15. 
revolutionary ideas. Its columns portrayed a "pleasant" life of the post-revolutionary Iran and also some place for anti-American propaganda was found. ${ }^{18}$

The Ishtar marked the attempt of the Assyrian community (or rather part of them) to adjust to the new circumstances. It is worth maintaining that before the Christmas of 1978 the local Christians received wishes from Ruhollah Khomeini, encouraging them to take active part in the revolution. ${ }^{19}$

In 1963, the Anğāman-e Ǎšurihā-ye Tehrān started publishing the paper entitled Kerkha Yerkhana. It lasted till 1971, and in 1978 it was reactivated, but only six issues appeared. After the revolution, in 1993, the Anğäman published the first issue of the Payām-e Ášuriyān.

The Payām is published monthly as a bilingual paper (Syriac and Persian). The paper is inscribed in the history of post-revolutionary Iran. The topics presented in the paper may be actually divided according to the Iranian presidency: Akbar Hashemi Rafsanjani (1989-1997), Mohammad Khatami (1997-2001) and Mahmud Ahmadinejad (2000 till now). The articles published during the presidency of Khatami presented a broad spectrum of social and political problems, discussions on the so-called "Assyrianess" reflecting national sentiments (with the problem of the language playing a significant role), presented impact of the Assyrians on the world history and civilization, described the Assyrian communities all over the world - in Armenia, Georgia, and the like. The president's speeches were reprinted in the paper. In fact, it was at that time when the president launched his program "Dialogue among civilizations."

It seems that for the Assyrians that period means searching for identity and stressing their historical roots and differences. The election of Ahmadinejad in 2005 broke such tendencies. During Ahmadinejad's presidency the editors have included many more articles on the integrity of the Assyrians with Iran as their homeland. It can be also seen in Ahmadinejad's public presentation that both the Assyrians and the president stress the unity of the Iranian nation (mellat-e Irān) ${ }^{20}$

\footnotetext{
${ }^{18}$ Cf. E. Naby, "Ishtar: Documenting The Crisis In The Assyrian Iranian Community," The Middle East Review of International Affairs 10 (2006) no. 4, pp. 92-102.

${ }^{19}$ Cf. H. Dehqani-Tafti, Masih va masihiyat nazd-e Irāniyān, vol. 1-3, Sohrab Books 1992-1994.

${ }^{20} \mathrm{Cf}$. Mahmud Ahmadinejad's speech: Ğām'e-ye Āšuriyān ğoz'-e mellat-e Irān hastand [The Assyrian Community is the part of the Iranian nation] on the President's web site: http:// www.president.ir/fa/?ArtID=21751 [30.10.2010]; and the statement of Yonathan Betkolia, the Assyrian deputy after the meeting with the Majlis Speaker Ali Larijani (9 May 2010), "We are of the belief that Iran is a model of freedom for other nations, and one fine example of that is the living conditions that the Islamic Republic has provided for the Assyrians in Iran"; http://www. tehrantimes.com/index_View.asp?code $=219086$ [30.10.2010].
} 


\section{The Institute of St. John Apostle in Tehran}

The presentation of the Assyrian (Chaldean) publication in Iran in the Persian language would be incomplete without mentioning the role of the Institute of St. John (Känun-e Yuhannā-ye rasul). The Institute was established in the 1990s at the Cathedral Church of St. Joseph and during that time it was under the directorate of Fr. Pierre Humblot.

Realizing the goals of Bishop Ramzi Garmou the institute publishes a number of books in Persian every year. Among them one can find the history of Eastern Christianity, the history of Christianity in Iran or Syriac poetry translated into Persian.

The workers of the Institute seem to prioritize translations. Some titles should be mentioned: Mazāmir va sorudhā-ye ketāb-e moqaddas, being the translation of the Book of Psalms or the translations of the documents of the Second Vatican Council.

The activities of the Institute, especially in the linguistic field, testify about the importance of the Persian language among the Iranian Christians. 
